\title{
The Beginning of Typographic Installation and Contemporary Graphic Creativity
}

\author{
SELMA KOZAK \\ Affiliation: Dokuz Eylül University, Izmir, Turkey \\ Faculty of Fine Arts, Graphic Department \\ E-mail: selmakozak@gmail.com
}

\begin{abstract}
Beatrice Warde's crystal goblet has changed the perception of typography and typographic expression in the print and online media since it was published. "Bear with me in this longwinded and fragrant metaphor; for you will find that almost all the virtues of the perfect wine-glass have a parallel in typography" (Warde, 1956, p. 1). Since 1932, when Warde introduced type and typography as a 'crystal goblet', typography has evolved significantly, and probably in the fastest way with the contributions of technological improvements and printing technologies. Typography has proliferated in the early decades of the 20th century as an essential and highly visible aspect of modern art and design. It has also became a production practice in post-modern art in the middle of the 20th century and early 21 st century.
\end{abstract}

As it is known, text is not new to art and avant-garde and so is typography. With postmodernism, the usage of text, type and typography in post-modern art practices, contemporary artwork examples, design arts, installations and conceptual art movements blurred the boundaries between art and typograph. Especially artists and designers started to use typography in their personal expressions as a post-modern art strategy and, as a result, typography became a hybrid form to assess in 21 st century art practices and also a raison d'être to convey idea, thought and message.

In this paper, by using the descriptive method, I will focuse on the relationship between typographic installation and contemporary graphic creativity. In this regard, evaluating Beatrice Warde's philosophy along with the samples of typographic installation of artists such as Sheila Levrant de Bretteville, Stephen Doyle, Barbara Kruger etc. and a special museum Deportee Memorial Museum Carpi, will be helpful in order to compare the changes in the past and present approaches in typographic applications and it will be useful in order to understand today's graphic creativity. 
Keywords: typography, typographic installation, Beatrice Warde, Sheila Levrant de Bretteville, Deportee Memorial Museum Carpi.

\section{Introduction}

What we call the beginning is often the end.

And to make an end is to make a beginning.

The end is where we start from. And every phrase.

And sentence that is right (where every word is at home,

Taking its place to support the others,

The word neither diffident nor ostentatious,

An easy commerce of the old and new,

The common word exact without vulgarity,

The formal word precise but not pedantic,

The complete consort dancing together)

Every phrase and every sentence is an end and a beginning. (T.S. Eliot, 1968)

In Little Gidding (1942) (final poem in Four Quartets), T. S. Eliot questions time, past and future, perspective, the beginning and the end etc. The beginning means opening a new chapter in history of anything and it means to initiate something that hasn't been done before and something that has a potential to influence others in some way or another that can shape the cultures, cultural conditions or sometimes ages.

Every age is defined by the art it inspires. For in every era, an elite group of works succeeds in transcending the tethers of history, the ephemeral intrigues of politics and the intimate entanglements of the artist's personal life, while at the same time capturing the essence of the generation that generated it. So what of our own era? (Grovier, 2013, p. 10).

In contemporary age, when considering the relationship between typography and contemporary graphic creativity and art, typography is a significant subject and a hybrid medium that both designers and artists use for personal expression, individual creativity, 
for the creation of artwork. Furthermore, in this connection, typography gains a leading role in our creative lives. Besides, typographic installation achieves the same status as well. From graphic designers to conceptual artists, from designers who make design arts to painters, artists use typography.

Typographic installation is both an individual and cultural expression that can define today's creativity. Here, the aim is not merely to learn about the works but to explore them for what they can tell us, and how they can build the profile of our age and the meaning of typographic installation today by using the descriptive method. Examples in the article give us some clues to articulate something fundamental about the era and its artistic sensibilities by focusing on mostly the American and Italian works (according to resources, a first example of modern typographic installation was by an Italian artist, Fortunato Depero, 1927. And after that, with conceptual art and postmodernism in the 1960s and 1970s, the use of typography in an artwork and public installation became more common among American artists), which are considered to be at the heart of contemporary creativity. Therefore it is possible to come to an understanding of today's typographic and artistic approaches by evaluating the artists'visions, skills and passions.

\section{Typographic Installation and Graphic Creativity}

"A bee that has seen a food source can communicate the message to bees that did not see it, but a bee that has not seen it cannot transmit the message to others that did not see it" (Deleuze and Guattari, 2005, p.77). Typography is perhaps the best way to convey the message and the idea to the others; and it makes the world readable and visible. Eyes focus on words. Deleuze and Guattari stated that as human beings, we can communicate, think, understand or perceive through what we see. In this case, the theory of Deleuze and Guattari related to visual world shows similarity with "The Allegory of the Cave" by Plato. In his book titled Republic (2020), Plato has also explained that our reality is based upon what we see.

We live in world of images and with the help of technological improvements and multimedia design tools, so creating images, texts, type or design has become easier probably more than ever in contemporary age. Moreover, in the 21st century, postmodern culture, digital culture or cyber-culture have caused the changing of design language and graphic creativity and so has typography. Nothing in the universe remains constant, and there is nothing that does not change or transform, or stays as it is. Fluidity of the universe alters time and the zeitgeist as well. Changing of time has also shifted typography and typographic expression. Designers and artists have begun to use typography in different 
forms, shapes, sizes, scale and began to use it from indoor to outdoor. Typography has evolved from two-dimensional to three-dimensional, from still to motion.

In addition, typography has the power to represent the spirit of the times and to reflect the characteristic of the context. In his essay titled The Philosophy of Modernism in Typography (1929), American typeface and graphic designer Douglas C. McMurtrie points out his philosophy which can guide not only modernism but also postmodern and contemporary age. According to McMurtrie,

"as all art of any vitality is a reflection of life, the typography which is truly representative of its period is expressive of the life of that period. Perhaps the most typical characteristic of present-day living is the quick tempo at which it moves. The tempo of our typography should be in keeping. It should be dynamic rather than static. Its balance should be that of motion rather than that of rest. The balanced composition suited to the leisurely contemplation of an earlier generation must give place to arrangements in which the sense of movement is inescapable. For we of the present age must, so to speak, read, as we run" (Bierut, Helfand, Heller and Poynor, 1999, p. 41).

In time, typographic expression has become enormous in terms of usage for almost all kinds of design and art. Nowadays, seeing large letters in the streets, on the walls of buildings, in the stations or any kind of places, is possible. Not only two-dimensional but also three-dimensional versions and different kinds of expressions or installations are visible. That kind of diversity has also brought designer and artist to the realm of freedom and extensive creativity, and it is a reflection of the spirit of postmodern world. The limitless utilization of typography, therefore, has led to a paradigm shift within typography itself. This also offers a new point of view on assessing typography within contemporary graphic creativity. In contemporary age, typography is in the leading role; and it connects directly to the context. Typography is as visible as possible and expressive, and sometimes context is transferred to the audience only through typography, as especially many of typographic installations are boisterous in terms of artist and designer's attitude, transfer of content, creativity skills, typeface, font, size, shape, scale, and material usage. Typography speaks with people, catches them and makes itself readable. It can also influence people's psychology and behaviour. In the 21st century, typography itself becomes protagonist. For this reason, one of the components of contemporary creativity is typographic installation.

At this point, however, the beginning and pioneers are significant to form a proper frame of the definition and explanation for typographic installation. Beginning means opening a 
new chapter in the history of anything. Accordingly, the pioneers of typographic installation have begun a new period in typography and postmodern graphic design. Avant-garde designers who pushed the boundaries from Futurism, Dada, Situationist International, Modernism or Postmodernism have considerably contributed to build a new experimental design approach by using typography and installation together. Thus, avant-garde vision has helped and still helps to shape the contemporary graphic creativity.

Typography (lettering) is as ancient as the history of humanity and lettering on stones and buildings dates back to cave people in the ancient times. Even though some instances, such as large letterings, advertisement signs and outdoor typography like HOLLYWOODLAND were designed by Thomas Fisk Goff in 1923 or some others were made from the 1930s, when it comes to modern typographic installation, in 1927 Italian Futurist graphic designer and painter Fortunato Depero designed and built perhaps the first building to be made out of concrete block letters for Bestetti, Tuminelli, and Treves Publishing Houses in book pavilion in Monza (Pavilion for the Monza Biennale Internazionale delle Arti Decorative, Monza, Italy). The book pavilion spells out the structure's function as a kind of "typography parlant" (typography whose physical form speaks to the semantic meaning of the words) (Heller and Ilić, 2013, pp. 10-22). The pavilion and the usage of typography were an experimental structure, which represented a new stage of avant-garde typography and the beginning of typographic installation.

"The end of 20th century saw the gradual breakdown of the hegemony of the International Style in the face of challenges that arose as part of the postmodern movement" (Eskilson, 2007, p. 336). Thus, the beginning of the 1970s and 1980s can also mark the rise of postmodern typography and typographic installation. Avant-garde designers and artists such as Barbara Kruger, Sheila Levrant de Bretteville, and Stephen Doyle have begun to produce typographic installation and public art.

A signature facet of postmodern graphic design is the fact that it is often combined with social activism on the part of the artists. This draws a stark contrast with the depoliticization that was characteristic of the International Style overall, and represents essentially a repoliticization of graphic design. This type of postmodern work is also another historicist impulse, as artist sought to intervene in the political discourse in the same way that earlier generations (the avant-garde of the 1920s) involved their profession in social action. (Eskilson, 2007, p. 369)

Design forms and terminology have political and social meaning, expressing attitude and values of their time; postmodernism gained a strong foothold among the generation of designers who emerged in the 1970s. (Meggs, 1998, p. 432) 
Barbara Kruger, for instance, is the most well-known art director, graphic designer and artist who has shifted her working from commercial design to art, particularly activist art. Kruger has created her signature style by combining dramatic photographs and strong declarative discourse. Later, Kruger started to produce huge typographic installation from public space to museums and galleries with her signature style designed by using Futura bold italic font. She made possible to see huge letters, words and strong messages wherever we look at. There is no escape among the words in her installation and a complete typographic interface. As typographic installation, Kruger's style and works are one of the most significant instances that create contemporary vision and cotemporary graphic language and also artistic discourse. Typography in her works is loud and clear. Without complex graphical aesthetic concern, conveying the message and the thought is the main purpose, which shows that this is an embracement of postmodern style.

On the other hand, according to Meggs (1998, p. 432), "postmodern designers place a form in space, because it "feels" right rather than to fulfil a rational communicative need. Much postmodernist design is subjective and even eccentric; the designer becomes artist performing before an audience with the bravura of a street musician, and the audience either responds or passes on." In 1996, for example, graphic designer Stephen Doyle created a typographic installation in Grand Central Terminal in New York.

The Nineteenth Amendment was created as a typographic installation commemorating the 75th anniversary of the amendment which granted women the right to vote. The text was applied to the floor of Grand Central Terminal in 9,276 point type. The Nineteenth Amendment, promising enfranchisement to women and suffrage regardless of sex, is reproduced on the floor of the Vanderbilt waiting room, which is traversed by millions of commuters daily, with the fanfare that these historic words deserve. (Doyle, 2021; Heller and Ilić, 2013, p. 106).

Installing the work in a station where thousands or millions of people walk every day means bringing the audience and artist together. The message conveyed is explicit and direct. During contemporary age and the times when we live so fast, typography is an indispensable tool and a medium for expression. Avant-garde spirit is around us and builds a contemporary style. Accordingly, in this example, as Meggs mentioned above, designer transforms and becomes an artist who performs inside and around the audience, sometimes in the street, sometimes in public or not. Furthermore, the audience walk with the artist every day with or without their awareness. 
Deleuze and Guattari point out that language is not content to go from a first party to a second party, from one who has seen to one who has not, but necessarily goes from a second party to a third party, neither of whom has seen. It is in this sense that language is the transmission of the word as order-word, not the communication of a sign as information (2005, p. 77).

Furthermore, typography is not just the organization of letters and words but is the language itself and a substantial form of art in contemporary society. At this point, it becomes an obligation to mention the term of langage. The grammar of art is langage. In the light of all mentioned above, the usage of typography is a graphical langage, especially in modern and postmodern age. However, in contemporary age, saying that typographic installation itself becomes a contemporary graphical langage will not be wrong.

Moreover, in contemporary age, the use of typography turns into an explanandum among artists and designers. In this regard, typography is a hybrid form which interconnets art and design as well as artist and designer and it becomes an aesthetic decision and a raison d'être. Besides, according to Heller and Ilić, "typographic installation and typographic art are accepted genres" (2013, p. 179).

As a result, typography is in leading role in contemporary age, particularly since the early 1900s when is the beginning of contemporary graphic design and typography. Also, typographic installation has the same leading position. And, basically, a definition can be given, i.e. that typographic installation is the installation which is formed by using letters, words; the installation with which walls, floors can be covered; the installation with which buildings, bridges, stairways and buses can be enveloped; the installation which can be placed in stations, or on fronts of buildings, trees, mountains or any kind of surface and space etc. by using any kind of material; the installation which is ephemerae or permanent. Anywhere is a tabula rasa for designer and artist.

In the 21 st century, we live in a completely digital age. Since 1990s, computer technologies, powerful design software and hardware system have made it possible to do anything, even the things we can barely imagine. Hence, artists and designers use these opportunities to produce LED installation, neon installation, or motion installation by using typography. These are the part of typographic installation and typographic art as well. In this sense, to understand contemporary graphic creativity also requires a good analysis of avant-garde, postmodern, typography, typographic installation in both graphic design and visual arts fields. As opposed to Beatrice Warde' theory given below, typography is not invisible but visible. In addition, it is never colourless. Contemporary graphic creativity includes all 
kinds of creative approaches and aesthetics expressions. Indeed, it consists of all of their components. Here, avant-garde, modern, postmodern and contemporary are in fusion according to time spirit.

\section{Beatrice Warde and Crystal Goblet}

Typography was known especially as a male-dominated area in the design realm. Besides, it is known that design's roots in the historically male-dominated world of typography and type design has led to gender inequality in recent history and modern day. No doubt that in a male dominated area, as a woman Beatrice Warde was a very significant woman designer and writer in the field of typography. In the 20th century, she was the first woman and one of the pioneers of importance in the history of the field, before Zuzana Licko or Carol Twombly, or Nelly Gable, who now cuts punches, as far as we know the first made ever by a woman, at the Imprimerie Nationale in Paris. Thus, she is an avant-garde and inspirational figure, who led her successors (Lussu, 2018; Morley, 2016).

On the other hand, the Crystal Goblet or Printing Should Be Invisible has been a controversial essay since it was published. In 1930, Beatrice Warde gave a lecture called "Printing Should Be Invisible" to Society of Typographic Designers at St Bride Institute in London. Then, in 1932, the text of the lecture was published under the title of The Crystal Goblet or Printing Should Be Invisible (Bierut and others, 1999, p. 56). Since then, much has been said and written on it, because Warde's essay had plenty of metaphors on typography or how typography should be. In the essay, Warde drew significant parallels between typography and a perfect wine-glass or a crystal goblet. According to Warde, transparency and invisibility of typography equaled to the crystal wine-glass. Whether or not we have seen the wine in this metaphorical rhetoric, we choose which glass we take between solid gold goblet and crystal-clear glass. According again to Warde, the only thing which matters is to see the wine. When it comes to typography, what matters is to read the text. And typography should be invisible and colourless. As Warde (1956, pp. 1-2), formulated

imagine that you have before you a flagon of wine. You have two goblets before you. One is of solid gold, wrought in the most exquisite patterns. The other is of crystal-clear glass, thin as a bubble, and as transparent. Pour and drink; and according to your choice of goblet, I shall know whether or not you are a connoisseur of wine... Bear with me in this long-winded and fragrant metaphor; for you will find that almost all the virtues of the perfect wine-glass have a parallel in typography. 
Here, Warde drew attention to readable typography, which conveys an idea and message. Beautiful solid gold goblet can not show the fine wine within, but crystal is clear. Accordingly, well-used type is invisible as type, just as the perfect talking voice is the unnoticed vehicle for the transmission of words and ideas.

Author Robin Kinross (2018), explaines why Warde chose the methaphor of wine-glass and the crystal goblet. It is because "she was speaking after dinner to the Society of Typographic Designers, and this explains something about the approach of her discussion and her metaphor of the wine glass-the 'crystal goblet'. " Giving the example of flagon and goblet has been criticized by writers and theorists of typography. If we look from the viewpoint of typography, Warde's methaphors "transparent typography" and "invisible typography" have been considered as stereotypical discourse among Modernist typographers, particularly after Bauhaus typographers introduced and embraced the modern and new typography. Nevertheless Kinross' argument can be reasonable but looking beyond that is an obligation in order to reach the final conclusion. According again to Kinross (2018),

What is a flagon? The word has gone from English usage. Flagons were perhaps last heard of in Errol Flynn movies of the 1950s, when men in tights jumped onto tables littered with goblets, and challenged each other to a sword-fight... Through the years of modernist ascendancy, in the 1960s and 1970s, the Crystal goblet essay was ignored. There was no need for it: transparency as an ideal was understood and accepted. But with what was sometimes known as the legibility wars of the late 1980s and early- to mid-1990s, Warde's essay was given a new life. The deconstructive critics sometimes suggested that transparent typography was not just a false theory, but was actually oppressive to the reader.

At this point, the questions "What is invisible typography?" and "What is transparency in typography?" are significant in order to analyse and compare Warde's perception of typography and the conditions of typography in contemporary age.

In June 2006, Giovanni Lussu and his colleagues, Antonio Perri and Daniele Turchi wrote an article that included a sharp and serious critique related to Warde's idea of typography for the Journal of Progetto Grafico (supported by AIAP, the Association of Italian Graphic Designers). Lussu and his colleagues analysed Warde's text in terms of rhetoric and language. According to Lussu, Perri, and Turchi (2018),

is out of question to read every text and books etc. in the same way. These two can not be adapted to all. It is hard to see what this invisibility is that Warde talks about. Indeed, 
it seems rather clear that in this case 'transparency', namely the possibility of getting quickly and surely to the 'wine' provided by the authors, is ensured by the fact that the typography is anything but invisible.

Furthermore, Lussu points out that type, size, bold and italic fonts, smal caps, compositions or columns used to form a composition are very visible differentiations that guarantee good assimilation of the texts. In this regard, his questions are as follows:

How could it be read without careful treatment of differences and visibility, without giving prominence to the numbering of the verses? Could we read Euclid's Elements in the form in which it was presumably written, with no differentiation between upper and lower case letters, without punctuation marks and without highlighting of the titles? (...) Since we are talking about things which are read and which are therefore assimilated by means of sight, it is very hard to separate the wine from the goblet, the text from its visible form" (Lussu and others, 2018).

"The Crystal Goblet", however, still gives us two different issues and discussion subjects or presumably more than two. Whether the essay is oppressive to the reader and stereotypical or to quote Warde (1956, p. 2),

one main idea that the most important thing is that it conveys thoughts, ideas, images, from one mind to other minds. This statement is what you might call the front door of the science of typography. Within lie hundreds of rooms; but unless you start by assuming that printing is meant to convey specific and coherent ideas, it is very easy to find yourself in the wrong house altogether.

On the other hand, in contemporary age, grandeur of typography has become the exuberant mannerism, with significant contribution to contemporary graphic creativitiy. Also, Meggs (1998, p. 432) states that "mannerism describes a departure from the norm by taking liberties with the classical vocabulary of form." The Age itself we live in is boisterous, so are typography and typographic installation. Extraordinary typographic and very unorthodox installations are a testimony of our age and a fascinating inspiration source to express artist and designer's thoughts, ideas, messages and contents in any subject. And the usage of typography is not neutral or invisible but completely opposite. As Heller and Ilić (2013, p. 10) stated "letterforms, which were never as neutral as Warde would have us believe, are often boisterous. Crystal goblets are routinely shattered in the service of today's typographic expression in print and online media." 
Despite all the critiques that have been made to the essay, as a result, many of typographic installations, typographic art and concept artists, who use typography to convey their standpoints have a common point with Warde, that typography should be readable to communicate. Today, typography is limitless. In addition, typography is a precious ingredient that allows us to gain a good quality of food.

\section{Sheila Levrant de Bretteville and Public Art}

In the public domain, in streets, people don't expect to see art. If you go to a museum you expect that everything inside there is art. In the street, if you stop on street, they look to see what is this thing? I think, then they are in a very questioning position. And they are open to seeing what it is. (de Bretteville, 2019)

Sheila Levrant de Bretteville is one of the legendary figures in graphic design. As a feminist and a woman, she is a pioneer in the realm of graphic design. In both graphic design and public art, her works reflect her political and activist approaches, which she tried to insert into public places expressing the voices of overlooked persons, groups of people and perspectives. According to de Bretteville,

I really do not like it when anyone is left out, in any situation - parties, admissions, neighborhoods. One way to compensate is to help others to pay attention to the people in the forgotten parts of cites. Whenever possible I choose marks such the ellipses' three dots ... which I see as giving a location for someone's else thoughts. (Sfligiotti, 2016)

Works of art can define our age. However, do they affect the society? Do they touch the people's lives in any way, anywhere? Do they create a utopian culture? In her essay tittled Some Aspects of Design from the Perspective of A Woman Designer, (1973), de Bretteville said that

the process by which forms are made, and the forms themselves, embody values and standarts of behavior which affect large numbers of people and every aspect of our lives. For me, it has been this integral relationship between individual creativity and social responsibility that has drawn me to the design arts. It is possible and profitable to reinforce existing values through design. In my work, however, I try to project alternative values into society in the hope of creating a new, even utopian culture, by acting in accordance with values of my own chosing. (Bierut and others, 1999, p. 238) 
"Every city is a paragraph. Every street, a sentence. Every building, a word. And those who inhabit the city whisper through its streets like syllables in search of a syntax or grammar that might give meaning to their lives" (Grovier, 2013, p. 150). Simply, public art is an art form that is made in public space, that can be a wide variety from ephemeral to permanent, from large scale to small. In de Bretteville's works, this diversity can also be seen. By using typography, the artist made enormous size of works. Typography is the protagonist in her works. In a meeting in September 2019, she explained that her choice of the use of typography in public art as follows: "If you are not there you have to use letters. If you are not going to be there yourself, you have to have words" (de Bretteville, 2019).

Cities as a whole have always been in a relationship with society, elements of society and the history of society. Every city is inescapably tied to its own characteristic. The cities affect people, but the people also influence the cities and every city evolves and builds according to its own texture. Thus, when society changes, the city changes either. The city also depends on direct relationship between people and groups (families, organizational structures, professions and corporations, etc.) In this context, when its relationship and communication with people is considered, the city and the using of the city mutually affect this change in terms of both social and urban axis. Accordingly, the city is not just a space where people live in, it becomes a space which has the opportunity to experience everything happened around them. de Bretteville (2019) points out her vision of public art that

I think, maybe it is different for me from the others. So, it's always giving to the neighborhood something that it doesn't have, not so much. You could say that any art piece did it. But I find out what they really need, a supposed to what they don't have. what's really needed in that places. That's important to me that they needed than just to make something look at but something that are actually pretty urgent that they need it. That's true in these projects.

Public art, on the one hand, not only contributes to the diversity of society but also has an active role to play in realizing and thinking people over the places where they live and how public space can be used in the city. On the other hand, it has the power to transform places into something else and to give a chance to sustain their existence through art. For instance, abandoned places turn into places for the people where they come together or walk through in safe. People can gather around them or can enjoy them or can learn from them. 
At the start... At long last... (1999), for example, she, indeed designed an interface of a whole station for the people who live there. 207th Street station in Inwood is the longest subway in New York. The design in the station is on the walls and on the floor. At the start... At long last... includes phrases. Both phrases reflect the experience of the subway travelers and the three dots of the ellipses invite them to finish the sentence after the ... with their own thoughts. Moreover, the artist tells the stories "from generations of people who have arrived or have left from this train station: Native Americans coming to a Pow Wow at Inwood Park, merchants of various shops, resident musicians, singers, dancers in shows downtown, designers, academics, artists and activists from countries in Europe, Asia, Latin America -and most recently from the Dominican Republic" (See Figure 1) (de Bretteville, 2021). In this context, here, the artist becomes a storyteller who narrated history from generation to generation through her artistic expression, through art, public art.
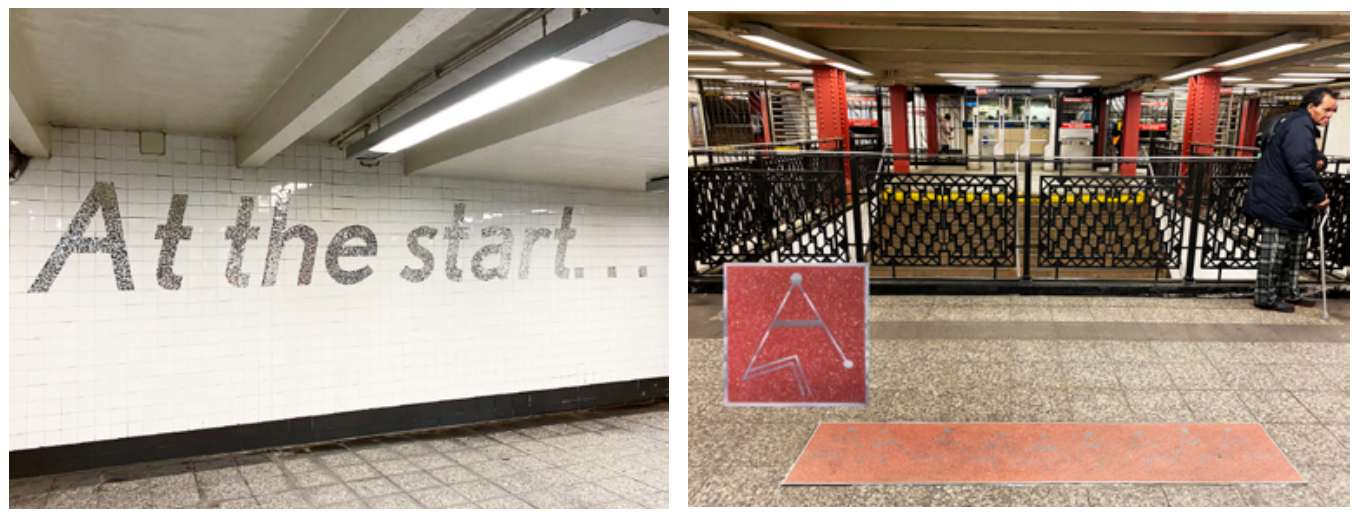

Figure 1: At the start... At long last... 1999, Sheila Levrant de Bretteville, photographed by Selma Kozak, 2019

Today, designers are more attracted to making public art; and typography is not just integrated into commercial design, it is also integrated into noncommercial art projects. Sheila Levrant de Bretteville is one of the first graphic designers and artists who made it, and she is one of the pioneers who shifted her personal expression from graphic design to more public art. Concrete and typography are in coherence in her works. Mostly, she has used these two elements. She indicates that "I knew about concrete because it is was very impressionable. To make permanent works, she who decided on concrete," she said (de Bretteville, 2019). Furthermore, her husband (Peter de Bretteville) is an architect, which was an effective factor for her to choose the concrete. When it comes to places, de Bretteville makes better to sides. Her contribution to cities as an artist is to make the places better, such as a side, a wall, a pedestrian path, a highway etc. 
I am choosing a side. What I am going to do on the side is obviously different and also I am competing against other people. They suggest something and I suggest other things at that side. Right! So, for me either I use the sidewalk or I am creating a wall was originally supposed to be there" (de Bretteville, 2019).

S.K: So, can I say, all of them have created to serve a purpose? They actually have a specific mission to give the people something.

de Bretteville: Right! They have mission to provide the people who are there with something that lift them up in some way or have them feel hopeful in some way or give them an understanding of what could be as well as what was. It is not only to tell them it was. What could be for them also. There is a kind of potential I am looking for something being open ended that people who live there or work there or move through there have something that can inspire them (de Bretteville, 2019).

West End Echoes, 1995, for instance, is a huge installation written The Greatest Neighborhood This Side Of Heaven (See Figure 2). The work was made:

to create a pedestrian path where the new highway would replace the elevated Green line and a thriving neighborhood has been razed four decades earlier. Highway abutments are representations of the old West End buildings. Names of obliterated streets are embedded in the new sidewalk where the old street pattern intersected the pedestrian path under the new highway. (de Bretteville, 2021)
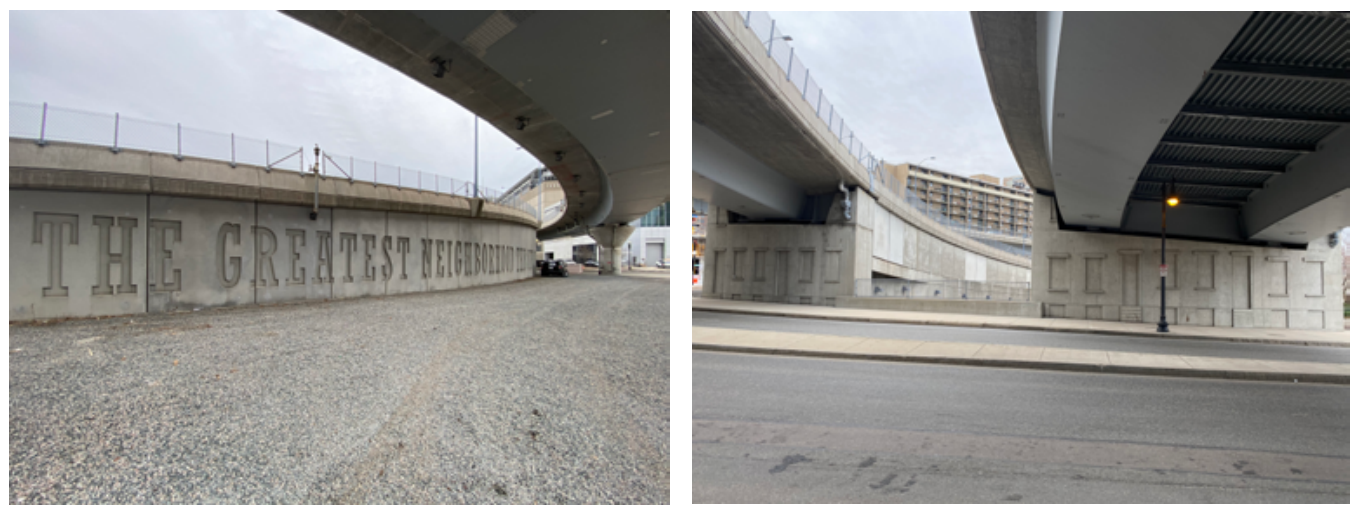

Figure 2: West End Echoes,1995, Sheila Levrant de Bretteville. photographed by Selma Kozak, 2019

de Bretteville works are completely samples of site-specific art. Her artworks have a particular location and an interrelationship with the neighborhood, with people. As de Bretteville (2019) stated "for me, I am interested in people who live there and some way 
to have them reflected in what has being done in their community and I look for having make a connection".

In addition, in the short or long term, site-specific art and site-specificity can make the connection the artists and designers look for. Mostly, "site-specific work focuses on establishing an inextricable, indivisible relationship between the work and its site and demands the physical presence of the viewer" (Kwon, 2002, pp. 11-12). Accordingly, the space of art is no longer perceived as an abandoned place, a blank slate, but as a real place. Jenny Holzer and Lawrence Weiner are probably the most well-known artists to convert a space into a space of art. Like Sheila Levrant de Bretteville, and Barbara Kruger,

Holzer and Weiner are also concerned with words, text, language, the power and ambiguous function of language as a means of communication. Jenny Holzer sees verbal ideas in the form of signs, as integral components of daily life. Her art appears in the form of texts, essays, posters and electronic message signs, mostly as a public art. (Landau, 1986)

One of the founding figures of conceptual art, Lavrence Weiner uses words and language as a material, redefining the relationship of "human beings to objects and objects to objects in relation to human beings" (Galerie Hubert Winter, 2021). By transforming how we see art, he transforms how we read the world. As Weiner stated "art is not a metaphor upon the relationship of human beings to objects and objects to objects in relation to human beings but a representation of an empirical existing fact" (Reading Resources, 2021; Galerie Hubert Winter, 2021).

\section{Deportee Memorial Museum, Carpi (1973)}

Consider if this is a man

Who works in the mud

Who knows no peace

Who fights for a bit of bread

Who dies because of a yes or a no.

Consider if this is a woman,

Without hair and without name 
Without enough strength to remember

Her eyes empty and her womb cold

Like a frog in the winter. (Primo Levi, 2013)

Although Nazis wanted to destroy and erase everything that remained from the holocaust and Jewish people, they could not achieve it. They could not erase the memories of victims at all, who survived the Nazi persecution. Primo Levi is one of the significant eyewitness who is a survivor from Auschwitz. Being a Jew, he was sent to Fossoli concentration camp near Modena, then to Auschwitz. He and his poem above (If This Is a Man, 1947) are magnificent testimonies of this wildness.

Fossoli concentration, camp which was originally constructed as a prisoner-of-war camp by the fascist regime, was used as a concentration camp later by Nazis during the World War II. The Deportees Memorial Museum of Carpi in Modena (Museo Monumento al Deportato Politico e Razziale di Carpi/ Italy), which was opened in 1973, is quite unique.

"The museum was opened for the memory of victims of Fossoli Camp, and it is very special, because the inside of museum is a unique structure that commemorates the Jewish deportation victims during World War II. The goal of the installation is to express the memory of this horror" (Heller and Ilić, 2013, p. 105). The museum consists of 13 various sized rooms where quotations (inscribed using the graffito method) create an intense emotional atmosphere in sombre and essential surroundings that at the same time remain reverential. The walls of some rooms are decorated with graffiti of sketches of great artists-Cagli, Guttuso, Leger, Longoni, Picasso, while the showcase contain significant exhibits that document the prisoners' lives in camp. The last room (The Room of the Names) which ends the visit, bears the inscription of about 15.000 names of Italian citizens deported to the camps. Outside the museum, visitors can see the "Cortile delle Stele": a squared area where 16 monoliths six meters high, face the engraved names of some Nazist concentration camps. (Fossoli Foundation, 2013).

The quotations in the museum are quotations that remained from the victims of the camp and bear the immortal significance of the victims' thoughts, which fill the visitors with a deep sense of participation. The usage of typography is intense. Words and sentences are clear like a crystal and the witnesses of that time. When it comes to design and typography, the museum is a coherent example of combination of concrete and letters. These two elements are representations of meaning of past painful time, concrete 
represents the coldness and typography becomes a vessel of meaning, a language of pain. The combination forms a poignant expression.
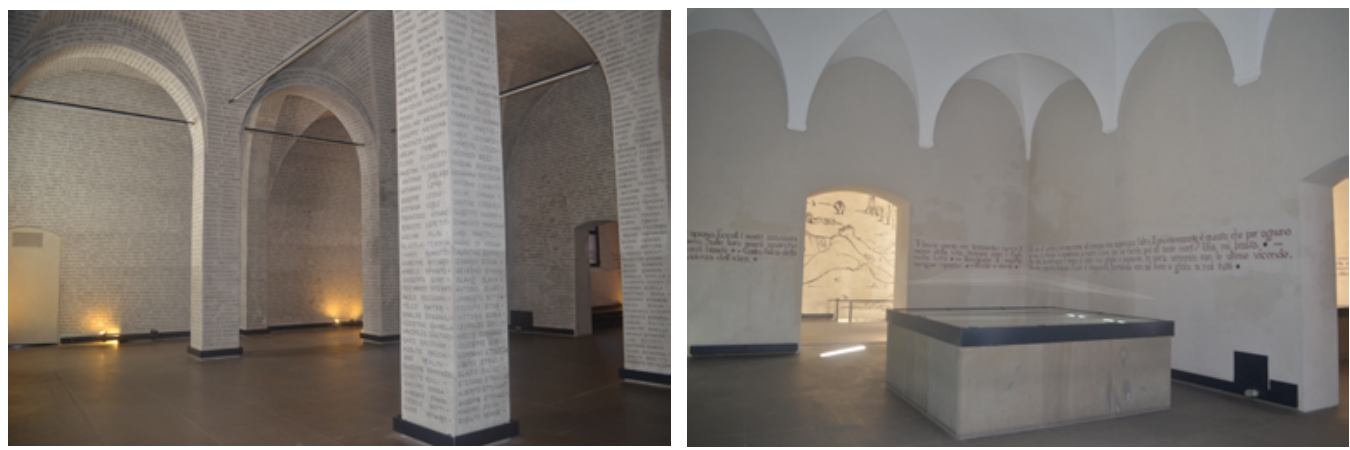

Figure 3: Deportees Memorial Museum of Carpi, The Room of the Names and One of the Rooms photographed by Selma Kozak, 2017

"Today they sentenced seven of us to be shot and sentence will be carried out in a short while. Nobody is afraid and many are even singing" (Milan, Yugoslavia), Room 2.

"Against the idea of violence, the violence of an idea" (Franz, Austria), Room 6.

"My daughter, your father will also be a mother to you..."(Olga, Rumania), Room 8. (Fossoli Foundation, 2013).

On the other hand, the museum itseif is a typographic installation that narrates bitter stories. Letters, words and sentences are a tool to convey pure painful stories. Hence, typography is in intermediary position here. Nothing is as tragical as the systematical killing in camps of over six million people. Therefore, the museums like in Carpi or The Memorial to the Murdered Jews of Europe in Berlin or Auschwitz-Birkenau Memorial and Museum in Poland and more are the museums standing against oblivion. Nothing has been left from them, and no one survived but at least their memories can be preserved. Thereby, generations can witness that dishonor in the history of mankind through museums. And humanist vision tries to preserve historical memory to remind us once and again 

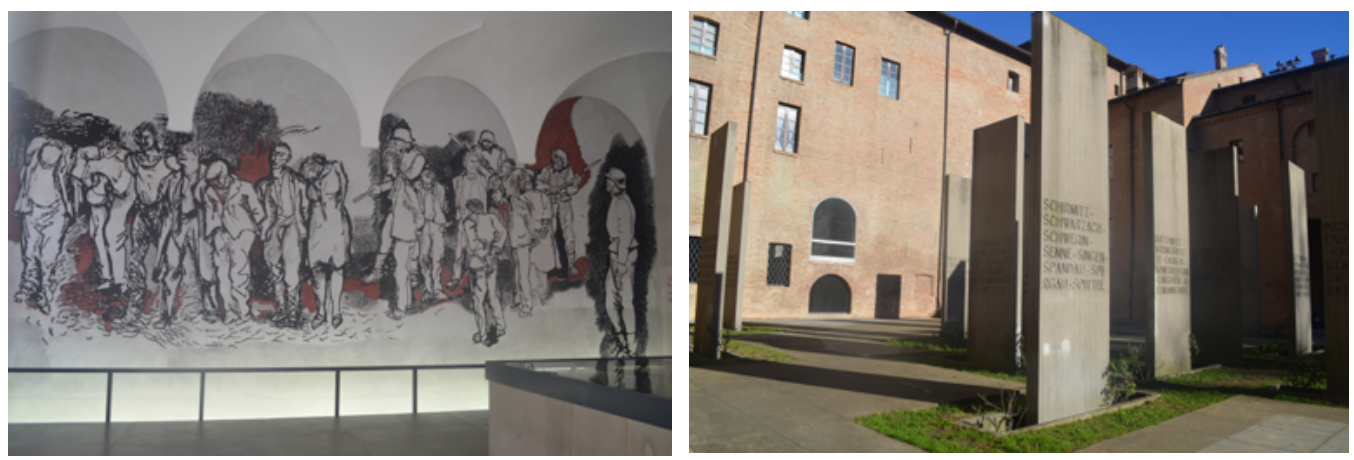

Figure 4: Deportees Memorial Museum of Carpi, One of the Rooms and Cortile delle Stele photographed by Selma Kozak, 2017

\section{Conclusion}

In contemporary age, typography and type can be anything from design medium to art, from art itself to structure, from signifier to artistic and aesthetic expression. Any surface is a tabula rasa for creator and for ideological rhetoric. And typography has always constant power to be delegate of our creative realm. In this regard, typography has became a hybrid form and a raison d'être for designers and artists from graphic design realm to art world.

The beginning of typographic installation has changed the design perception, especially in outdoor, in the street and has begun to create a contemporary interface. In this sense, typographic istallation has become a contemporary graphical langage. Moreover, typographic installation and typographic art are accepted genres today. Types, letters, words are the voices of artists and designers. They speak with these letters, which can be seen in any place from street to building, from museum to gallery, from bridge to LED screens.

\section{References}

Bierut, M., Helfand, J., \& Heller, S., \& Poynor, R. (1999). Looking Closer 3 Classic Writings On Graphic Design. Allworth Press.

de Bretteville, S. L. (2019). Interviews With Professor Sheila Levrant de Bretteville. (interviewer S. Kozak), September 25, Yale School of Art, New Haven, Connecticut.

de Bretteville, S. L. (2021). Sheilastudio. Sheilastudio: http://sheilastudio.us/ January 30, 2021

Debord, G. (2014). The Society of Spectacle. Bureau Of Public Secrets.

Deleuze, G., Felix, G. (2005). A Thousand Plateaus Capitalism and Schizophrenia. The University of Minnesota Press.

Drucker, J. (1994). The Visible Word Experimental Typography And Modern Art, 1909-1923.

The University Of Chicago Press. 
Eskilson, S. J. (2007). Graphic Design A New History. Laurence King Publishing. Eliot, T. S. (1965). Thomas Stern Eliot Seçme Şiirler (O. Türkay, Trans.). Yeditepe Yayınları. Eliot, T. S. (1968). Four Quartets. Mariner Books, Houghton Mifflin Harcourt Publishing. Fossoli Foundation. (2013). Museo Monumento Al Deportato/ Deportee Memorial Museum. Carpi. Fossoli Foundation.

Galerie Hubert Winter. (2021). Lawrence Weıner. Statement. https://www.galeriewinter. at/kuenstler/lawrence-weiner/lawrence-weiner-statement/ February 20, 2021.

Grovier, K. (2013). 100 Works of Art That Will Define Our Age. Thames \& Hudson.

Hale, S., Wolverton, T. (2011). From Site to Vision: The Woman's Building in Contemporary Culture. Otis College Of Art And Design.

Heiferman, M. (2005). City Art: New York's Percent for Art Program. Merrell Publishers.

Heller, S., Ilic, M. (2013). Lettering Large: Art and Design of Monumental Typography. The Monacelli Press.

Kinross, R. (2018,). For A Typography of Details. Hyphen Press. https://hyphenpress. co.uk/journal/article/for-a-typography-of-details?fbclid=IwAR1-ntFaJKg2rux9DEhDN1bTpu_sBeCKXs-ljWBaCt7VN_G60jc7CTt9iE0 March 13, 2021

Kwon, M. (2002). One Place after Another: Site-Specific Art and Locational Identity. The MIT Press.

Landau, S. (1986).Jenny Holzer, Barbara Kruger, The Israel Musem, Jerusalem. Exhibition Catalog, Hamakor Ltd.

Levi, P. (1992). Boğulanlar, Kurtulanlar. Can Yayınları.

Levi, P. (2011). Şimdi Değilse Ne Zaman? Efil Yayınevi.

Levi, P. (2013). If This Is a Man, The Truce (S. Woolf, Trans.). Abacus.

Losi, M. (2016). Guida Al Museo Monumento Al Deportato Politico E Razziale Di Carpi. Bononia University Press.

Lussu, G., Perri, A., \& Turchi, D.(2018). Wines and Goblets Should Beatrice Warde's 'Crystal Goblet' Be Seen, at Best, as a Harmless Promotion of Monotype? Medium: https:// articles.c-a-s-t.com/lussu-file-2-wines-and-goblets-2ac327e8f416, March 8, 2021

Meggs, P. B. (1998). A History of Graphic Design. John Wiley \& Sons, Inc.

Morley, M. (2016). The Women Redressing the Gender Imbalance in Typography: https://eyeondesign.aiga.org/the-women-readdressing-the-gender-imbalance-in-typography/?fbclid=IWAR03XaFT2MynuEecQalyoYI8zD. TImFdxfRV3KX6AcuDWLHUKONHMbY7DNE, March, 10, 2021.

Munro, E. (1979). Originals: American Women Artists. Simon And Schuster.

Oppenheimer, S. (2016). Women's Caucus for Art, Honor Awards for Lifetıme Achievement in the Visual Arts: Sheila Levrant de Bretteville. 2016 National Lifetime Achievement Awards, pp. 14-17.

Platon. (2020). The Republic. Is Bankası Yayınları.

Reading Resources. (2021). Lawrence Weiner. http://54.152.78.161/lawrence-weiner.

Sfligiotti, S. (2016). Being Otherwise. Progetto Grafico: https://medium.com/progetto-grafico/being-otherwise-b9ccbfca503a March 17.

Yale School of Art. (2021). Celebrating Yale School of Art's 150th Year. Yale School Of Art: https://www.art.yale.edu/150th, February 1, 2021. 